\title{
Introduction and How Fusion Can Help You
}

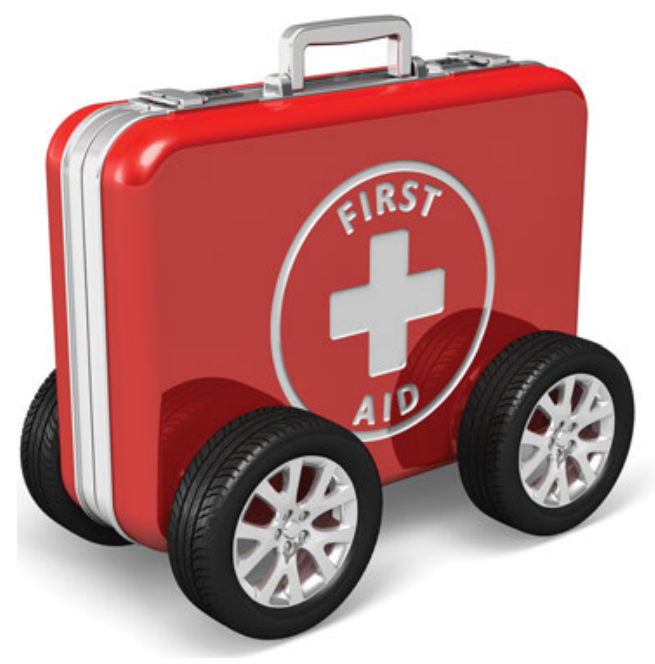

Figure 3: Can healthcare learn from a Formula 1 pit crew? Yes!

\begin{abstract}
Bringing in ideas from analogous fields turns out to be a potential source of radical innovation. When you're working on a problem and you pool insights from analogous areas, you're likely to get significantly greater novelty in the proposed solutions, for two reasons: People versed in analogous fields can draw on different pools of knowledge, and they're not mentally constrained by existing, "known" solutions to the problem in the target field. The greater the distance between the problem and the analogous field, the greater the novelty of the solutions . . . consider our recent study in which we recruited hundreds of roofers, carpenters, and inline skaters to contribute their insights to the problem of workers' reluctance to use safety gear because of discomfort. . . . Each group was significantly better at thinking of novel solutions for the other fields than for its own.
\end{abstract}

- Nikolaus, Marion, and Martin (2014)

What feature did mobile phones get from toasters? Pop-ups, of course! (Hence, the cover image on this book.) Whether you can't imagine life without pop-up notifications or you do imagine such a life and wish for it, the concept is the same: an idea from one place, transported somewhere new, can lead to radically creative innovation.

Case in point: Hospitals and Formula 1 racing (see Figure 3). A hospital emergency-room staff hired a design thinking team to make the emergency room "better." After consideration, the combined team decided that "better" meant "faster" and "right" - giving the right treatment quickly, since a patient could die without such care. Where could they go for inspiration? 
Formula 1 racing, of course! They went out for a day of racing, sat next to the pit crew, and when car-patients rolled in, they watched the crew quickly and correctly "treat" each one and send them off. They peppered one another continually with comments like, "Hey - that's a good idea! Why don't we do that? We should do that!" They gathered loads of ideas, instituted them in the hospital, and provided dramatically improved treatment, saving more lives than ever before. They didn't stop there, though. They invited the pit crew into the hospital and said, “Here's what we do. How would you do it?” Again, they gathered fresh new ideas from a previously untapped source and made life better for patients and staff.

There's actually a term for this - lateral thinking (or analogous thinking).

When this sort of thinking leads to new inventions, companies, industries, fields, and human capabilities, it's more than just thinking. It becomes lateral innovation. I introduced the concept in Innovation through Fusion: Combining Innovative Ideas to Create High-Impact Solutions, as well as companion audiobooks (1) Innovation through Fusion: High-Impact Innovation Method, Stories, and Community and (2) Innovation through Fusion: High-Value Lateral Innovation Intro.

So, now there's a term for lateral innovation - fusion.

The basic idea is this: nuclear fusion releases a great deal of energy when two nuclei combine. Likewise, a combination in business, science/technology, and the arts/humanities can release a great deal of value into the world.

Case in point: Martin Rothblatt introduced satellite technology into a stodgy, old industry: radio. Sirius Satellite Radio was born and evolved into Sirius XM Holdings Inc., now worth USD 25 billion.

The innovator crosses some sort of boundary - of technology, industry, nation, field, organizational silo, and so forth - and integrates ideas, people, technology, or something in a radical, new way. This type of innovation is often high value and catalyzes radical change.

People who do this are called "fusioneers." They begin their fusion journey by learning across multiple fields and building a broad array of knowledge and skills, making them also "polymaths." In fact, the founders of the world's five largest companies are (or were) polymaths: Jeff Bezos, Warren Buffett, Bill Gates, Steve Jobs, and Larry Page (Simmons, 2018). Modern examples include Elon Musk and Mark Zuckerberg. Historical examples include Marie Curie, Isaac Newton, Theodore Roosevelt, Thomas Jefferson, Benjamin Franklin, John Adams, Leonardo da Vinci, Michelangelo, Galileo Galilei, Aristotle, Marcus Aurelius, and Archimedes.

Not only do we see individual examples, but industries, too, are either merging or simply borrowing ideas from one another, such as the following (Vullings and Heleven, 2015):

- Sushi bars use the same carousel system that airports use for baggage.

- McDonald's drive-through uses similar techniques to Formula 1 pit crews. 
- Inspired by mobile phone pay-as-you-go services, Norwich Union introduced Pay As You Drive ${ }^{\mathrm{TM}}$ car insurance.

- Boatbound uses Airbnb's business model for boat rental.

- Inspired by retractable landing gear, retired aeronautical engineer Owen Maclaren developed the first lightweight baby stroller for his daughter, who had trouble getting in and out of airplanes with existing prams.

- Vacuum design and manufacturing company Dyson adapted a design from a nearby sawmill into its products - using a high cone to spin out dust via centrifugal force.

- Wine makers have begun to protect bottles during shipping with an adaptation from the egg carton.

- Phonebloks makes their telephone components from LEGO®-style pieces that can be swapped out for repair or upgrade.

- Solar panels and new fixtures have been installed in phone boxes on Tottenham Court Road in London, making them into mobile phone chargers.

Beyond industries and industry-based ideas, fields themselves are merging. Biology and technology are highly respected fields. When combined, bio-tech became a fast-growing industry with high-value innovations. Not only do we see pairs of fields combining, but now whole clusters of them are creating new value. One of the fusioneers I wrote about works in psychoendoneuroimmunology (PENI).

The sort of value Fusioneers have created (the ones I studied) is outlined in Table 1. Although I set out to study innovators, I found that 90 percent of them are also entrepreneurs and/or intrapreneurs (employee-entrepreneurs crafting new business for their companies), so theirs were not only personal stories of innovation; theirs were also stories of new companies and even whole new fields. This type of innovation is powerful.

Once I started speaking and writing about fusion at the level of the leader/ innovator, company, and industry, people started asking for more examples and sharing new ones with me. In the following pages, I share these with you, plus more that have been collected especially for this book. Some are famous examples you would have heard about (like Coca-Cola or Disneyland). Some are not so famous (like Legal Grounds). I include some products you have probably used (like VELCRO ${ }^{\circledR}$ ) and those I hope you haven't needed (like Given Imaging).

Since my previous book on fusion focused more on the innovators themselves, this book focuses on ideas, inventions, and companies that have revolutionized industries (or are about to) - hence the title.

I hope these examples of fusion inspire you to create new inventions, companies, and more. They are meant to inspire, illustrate, and get your creative juices 
Table 1: A few companies/organizations and their impact from Innovation through Fusion Combining Innovative Ideas to Create High-Impact Solutions (2020).

\begin{tabular}{|c|c|}
\hline Company/Organization & Impact \\
\hline Vaxess Technologies & $\begin{array}{l}\text { Millions of lives and USD } 16 \text { billion/year to save with non- } \\
\text { refrigerated vaccines }\end{array}$ \\
\hline ipac securities & More than USD 15 billion under management \\
\hline SwineTech & USD 8 billion/year in agriculture to save worldwide \\
\hline XCyton Diagnostics Limited & $10+$ million lives and USD 1.2 billion/year to save worldwide \\
\hline $\begin{array}{l}\text { KFC, Hungry Jack's, and } \\
\text { Domino's Pizza Australia }\end{array}$ & USD 1 billion+ business built \\
\hline Nokia Ringtones and Life Tools & $\begin{array}{l}\text { World's first digital music deal (pioneer in a USD } 2 \text { billion } \\
\text { industry) and } 125 \text { million subscribers }\end{array}$ \\
\hline Menulog & USD 850 million founding team \\
\hline NetForm & $\begin{array}{l}\text { One of the } 100 \text { most innovative firms in the world ( } \mathrm{ClO} \\
\text { magazine ranking) }\end{array}$ \\
\hline SensPD and BioHug & Age 0-4 intervention for 2 million people/year \\
\hline $\begin{array}{l}\text { Loreto Day School Sealdah and } \\
\text { Kolkata Mary Ward Social } \\
\text { Centre }\end{array}$ & 450,000 lives improved \\
\hline FutureMap and Hybrid Reality & $\begin{array}{l}\text { Million-view TED Talk, best-selling books, and leading-edge } \\
\text { consulting }\end{array}$ \\
\hline Against All Odds & $\begin{array}{l}\text { One of the } 25 \text { coolest companies in America (Fortune } \\
\text { magazine ranking) and record-breaking publishing }\end{array}$ \\
\hline $\begin{array}{l}\text { Execu-Care Coaching and } \\
\text { Consulting and Restoration } \\
\text { Vacation }\end{array}$ & $\begin{array}{l}\text { Thinkers } 50 \text { resilience pioneer and new technology to fight } \\
\text { the USD } 50 \text { billion/year burnout epidemic }\end{array}$ \\
\hline Lime.com & $\begin{array}{l}\text { Multiple Emmy Awards and the first integration of TV, radio, } \\
\text { Internet, video on demand (VoD), and mobile }\end{array}$ \\
\hline Lapis Digital/Vertic & Emmy Award-winning interactive TV and digital marketing \\
\hline NSW Institute of Sport & The Olympics' top score \\
\hline
\end{tabular}


flowing. Photographs and illustrations are provided to stimulate, amuse, enliven, and invite thought. They are more art than example, unless otherwise noted.

Even if you're not keen to create a new company or field, is fusion still a helpful concept? Yes. More than one person has approached me and said they recognized themselves in the concepts and never had a language for what they had done or validation that it is a good thing (see Figure 4).

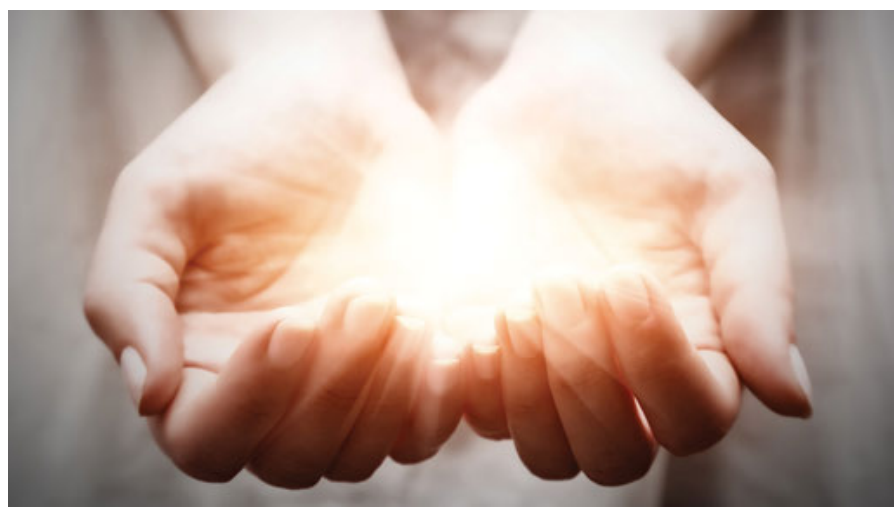

Figure 4: You, too can harness fusion.

Some were entrepreneurs, but some were employees who had created a great deal of value at work or who had crafted unique careers that spanned multiple fields. An example of the former used the company's technology in a new way to pioneer new services, helping his company grow and even become a Harvard Business School case study. He became a C-suite executive who always had new and interesting work at hand. An example of the latter thrived as both a singer and a marketer, flourishing both by applying her full range of skills and networks in both.

Yesterday's key to success was to become the best in the world at one thing, no matter how small. However, new research (Simmons, 2018) shows that it's just as effective (not to mention much easier) to be in the top 25 percent in two or more things. A polymath "future proofs" his or her career by turning to one set of skills or another, depending on what's needed in the moment, and he or she can earn well by being a unique resource with the power to demand a premium. Actually, it's easier than ever, now, to become competent in a new skill or field, with the rise of the Internet, online learning, and new AI-enabled learning engines (for example, EdCast).

More than 10 studies show a strong correlation between the number of interests/competencies and a person's creative impact. According to a 1,500-CEO 
survey by the design and consulting firm IDEO, creativity is the most important leadership trait (Sato, 2013).

In sum, with mental diversity (collect the dots) and creativity (connect the dots), we create new things of value. We keep some of that value and are better positioned to do it again. In a world that is constantly changing and looking for the newer and better, innovation may be the only sensible journey to make. New ways to innovate - with new language and concepts, as well as examples of others who've been there - should help.

In that spirit, I invite you to use these new concepts and language, reflect on your own journey to date, and gain inspiration from the stories below.

I've posted some additional material on two websites - S P Jain School of Global Management (www.globalinnovation.spjain.org/famous-fusions) and my own website (www.drcjmeadows.com/famousfusions). Companion material will also be available on GnowbeLearn ${ }^{\mathrm{TM}}$ (https://learn.gnowbe.com/), where you'll be able to watch video summaries, answer reflective questions meant to spur you to action, and craft your own fusion journey as part of a community.

There are many more examples of fusion in the world, and I invite you to share your favorites with me so I can share them with others. They may be stories from the media (please share a link or book/article reference, if so) or your own story of fusion innovation past or present. Just email me at cj@drcjmeadows.com

I thank you in advance and wish you a wonderful innovation journey! 